\title{
STRUKTUR DAN KEBIASAAN MAKAN KOMUNITAS IKAN DI ZONA LIMNETIK WADUK IR. DJUANDA, JAWA BARAT
}

\author{
Endi Setiadi Kartamihardja") dan Chairulwan Umar")
}

\begin{abstract}
ABSTRAK
Waduk Djuanda dengan luas permukaan air maksimum 8.300 ha termasuk perairan yang subur (eutrofik) dan sebagian besar $(80 \%)$ dari luas tersebut merupakan wilayah limnetik. Studi struktur, makanan, dan kebiasaan makan komunitas ikan di wilayah limnetik Waduk Djuanda telah dilakukan selama 1 tahun dari bulan April 2003 sampai dengan Maret 2004. Penelitian ini bertujuan untuk mempelajari status struktur komunitas ikan dan peranan dalam memanfaatkan sumber daya pakan yang tersedia. Penelitian dilakukan di 9 stasiun penelitian yang meliputi seluruh wilayah limnetik waduk. Pengambilan contoh ikan dilakukan dengan menggunakan 3 set jaring insang dan setiap set terdiri atas 9 pis jaring dengan ukuran mata berbeda, 9 dari 1,0 sampai dengan 5,0 inci. Jaring insang dipasang secara acak di setiap stasiun pada sore hari dan diangkat pada pagi keesokan hari. Struktur komunitas ikan dianalisis secara deskriptif menurut waktu dan stasiun pengamatan. Makanan dan kebiasaan makan dianalisis menggunakan indeks preponderan, luas relung, dan tumpang tindih relung makanan. Hasil penelitian menunjukkan bahwa struktur komunitas ikan di wilayah limnetik Waduk Djuanda didominasi oleh ikan bandeng (Chanos chanos), nila (Oreochromis niloticus), oskar (Amphilophus citrinellus), dan kongo (Tilapia butikoferi). Keempat jenis ikan tersebut terdistribusi di ke-4 daerah pengamatan. Keragaman jenis dan frekuensi jumlah ikan yang tertangkap paling tinggi terjadi di daerah genangan utama waduk (stasiun III) dan daerah budi daya ikan dalam karamba jaring apung (stasiun IV). Ikan bandeng dan nila termasuk ikan planktivor dengan makanan utama fitoplankton, sedangkan ikan oskar dan kongo termasuk ikan omnivora yang cenderung bersifat karnivora dengan makanan utama zooplankton dan potongan ikan. Ikan oskara dan kongo mempunyai luas relung makanan yang lebar, sebaliknya dengan ikan bandeng dan nila. Indeks tumpang tindih makanan yang mengatakan tingkat peluang kompetisi makanan terjadi antara ikan bandeng dengan nila serta antara ikan kongo dengan oskar. Peluang kompetisi makanan paling rendah terjadi antara ikan kongo dengan bandeng dan nila. Ikan bandeng direkomendasikan sebagai ikan tebaran, karena dapat memanfaatkan fitoplankton yang berlimpah dan mempunyai harga jual yang relatif mahal jika dibandingkan ikan nila dan mas (Cyprinus carpio).
\end{abstract}

KATA KUNCI: struktur komunitas ikan, makanan, kebiasaan makan, zona limnetik, waduk

ABSTRACT: Structure, food, and feeding habits of fish community in limnetic zone of the Djuanda reservoir, West Java. By: Endi Setiadi Kartamihardja and M. F. Rahardjo

The Djuanda Reservoir, a eutrophic water has a maximum surface area of 8,300 ha and about $80 \%$ of its area was a limnetic zone. A study, was aims to gain data and information on structure of the fish community occupying the limnetic zone and their roles in utilization of the food resources. The study was conducted from May 2003 to April 2004. Three units of experimental gillnets composting of 1.0 to 5.0 inches mesh stretch were fished at three fishing areas for every month. Structure of the fish community was analyzed descriptively based on temporal and spatial distribution. Food and feeding habits of the fish species were analyzed using index of preponderance, niche breadth, and niche overlap. Results show that structure of fish community in the limnetic zone composed of 7 species and four species, namely milkfish (Chanos chanos), nile tilapia (Oreochromis niloticus), oskar (Amphilophus citrinellus), and kongo (Tilapia butikoferi) dominated of the catch. The four dominant species spread at all over the limnetic zone. The highest diversity and frequency number of the fish species occurred at the main limnetic area (station III) and at the cage culture area (station IV). Milkfish and tilapia is classified into planktivorous, mainly feed on phytoplankton, while oskar and kongo are omnivorous, mainly feed on zooplankton and fish fragments. The oskar and kongo have the widest niche breadth, reversible with the milk fish and nile tilapia. The diet overlap index was biologically significant between milkfish and nile tilapia and between oskar and kongo fish. The lowest diet overlap occurred among the kongo, milk fish and nile tilapia. The milk fish was recommended as a candidate of introduced species, since the species could utilized the phytoplankton abundance, relatively fast growth and has the higher price compare to nile tilapia as well as common carp (Cyprinus carpio).

KEYWORDS: fish community structure, food, feeding habits, limnetic zone, reservoir

\footnotetext{
Peneliti pada Pusat Riset Perikanan Tangkap, Ancol-Jakarta
} 


\section{PENDAHULUAN}

Secara morfologi, Waduk Djuanda yang luasnya maksimum mencapai $8.300 \mathrm{Ha}$, berpantai curam dengan kemiringan rata-rata lebih dari $40^{\circ}$ dan rata-rata kedalaman perairan $37,5 \mathrm{~m}$, sekitar $80 \%$ dari luas total merupakan ekosistem wilayah limnetik, yakni bagian tengah perairan atau bagian pelagis waduk setelah wilayah littoral dengan kedalaman air sampai dengan titik kompensasi (Jeffris \& Mills, 1990).

Waduk Djuanda mengalami eutrofikasi yang sangat cepat terutama setelah berkembang budi daya ikan dalam karamba jaring apung. Beban masukan unsur $\mathrm{N}$ dan $\mathrm{P}$ yang berasal dari pakan yang terbuang dan kotoran ikan budi daya menjadi faktor utama pemicu eutrofikasi. Unsur $\mathrm{N}$ dan $\mathrm{P}$ tersebut merupakan unsur utama yang dibutuhkan bagi pertumbuhan fitoplankton sehingga kelimpahan dan biomassa fitoplankton akan meningkat dan merupakan sumber daya pakan alami potensial bagi ikan pemakan plankton. Proses eutrofikasi yang terjadi akan mempengaruhi dinamika ekosistem waduk, baik dinamika faktor abiotik maupun faktor biotik termasuk komunitas ikan yang menghuni waduk tersebut.

Sejak Waduk Djuanda selesai dibangun pada tahun 1967, struktur komunitas ikan yang menghuni waduk mengalami perubahan. Pada awal penggenangan wạduk, struktur komunitas ikan diisi oleh jenis-jenis ikan asli yang menghuni Sungai Citarum dan tercatat 23 jenis di mana separuh dari jumlah spesies ikan asli tersebut termasuk famili Cyprinidae (Sarnita, 1977). Pada tahun 1987, struktur komunitas ikan mengalami perubahan setelah dilakukan introduksi ikan sehingga struktur komunitas ikan terdiri atas 23 jenis ikan asli Sungai Citarum dan 8 jenis ikan introduksi (Sarnita, 1987). Dalam perkembangan, struktur komunitas ikan ini akan mengalami perubahan dan hanya akan terdiri atas 2 kelompok yaitu jenis ikan asli Sungai Citarum yang mampu beradaptasi dengan perairan waduk yang terbentuk dan kelompok jenis ikan eksotik baik ikan yang sengaja ditebarkan atau diintroduksikan maupun jenis ikan yang lepas dari karamba jaring apung. Karakteristik struktur komunitas ikan dan peranan dalam memanfaatkan sumber daya pakan yang tersedia, khusus di wilayah limnetik waduk merupakan hal penting untuk dipelajari dalam kaitan dengan optimasi pemanfaatan sumber daya perairan bagi perikanan. Kompetisi pemanfaatan sumber daya pakan oleh ikan dapat diketahui dengan mempelajari luas relung (niche breadth) dan tumpang tindih makanan (niche overlap) ikan (Wallace, 1981). Informasi yang berkaitan dengan struktur dan kebiasaan makan komunitas ikan di wilayah limnetik waduk di daerah tropis sangat minim.

Kajian tentang struktur dan kebiasaan makan komunitas ikan di wilayah limnetik Waduk Djuanda bertujuan untuk mengetahui kondisi struktur komunitas ikan, interaksi antar jenis ikan, dan peranan dalam memanfaatkan sumber daya pakan alami yang tersedia. Data dan informasi tersebut akan berguna dalam rangka mengoptimalkan pemanfaatan dan pengelolaan sumber daya perikanan.

\section{BAHAN DAN METODE}

\section{Cara Pengambilan Contoh Ikan}

Pengambilan contoh ikan dilakukan di 4 daerah penelitian yang mewakili wilayah limnetik waduk Djuanda (Gambar 1) setiap bulan selama 12 bulan dari bulan Mei 2003 sampai dengan April 2004. Percobaan penangkapan ikan dilakukan dengan menggunakan alat tangkap gillnet monofilament dimana untuk setiap set gill net terdiri atas 9 pis dengan ukuran mata jaring 1 sampai dengan 5,0 inci. Tiga set gill net dipasang secara acak di tiap daerah penelitiar, pada sore hari dan diangkat pada pagi ke esokan hari.

Ikan hasil tangkapan dicatat jenis, diukur panjang total dengan ketelitian $0,1 \mathrm{~cm}$ dan ditimbang bobot dengan timbangan duduk yang mempunyai ketelitian $5 \mathrm{~g}$. Seluruh ikan yang tertangkap dibedah, diamati gonad, dan diambil saluran pencernaan untuk kemudian diberi label dan diawet dengan formalin $40 \%$. Ikan hasil tangkapan tersebut dikelompokkan berdasarkan pada waktu dan daerah tertangkap.

\section{Analisis Struktur Komunitas Ikan}

Struktur komunitas ikan dianalisis berdasarkan pada komposisi jenis ikan yang tertangkap di wilayah limnetik menurut waktu dan tempat pengambilan contoh. Setiap jenis ikan dikelompokan menurut ukuran panjang total untuk kemudian dipresentasikan dalam histogram frekuensi panjang total. Histogram frekuensi panjang total untuk setiap jenis ikan dianalisis secara deskriptif untuk mengetahui sebaran baik secara spasial maupun temporal.

\section{Analisis Makanan dan Kebiasaan Makan}

Jenis makanan ikan diamati dengan cara mengidentifikasi isi saluran pencernaan. Kebiasaan 


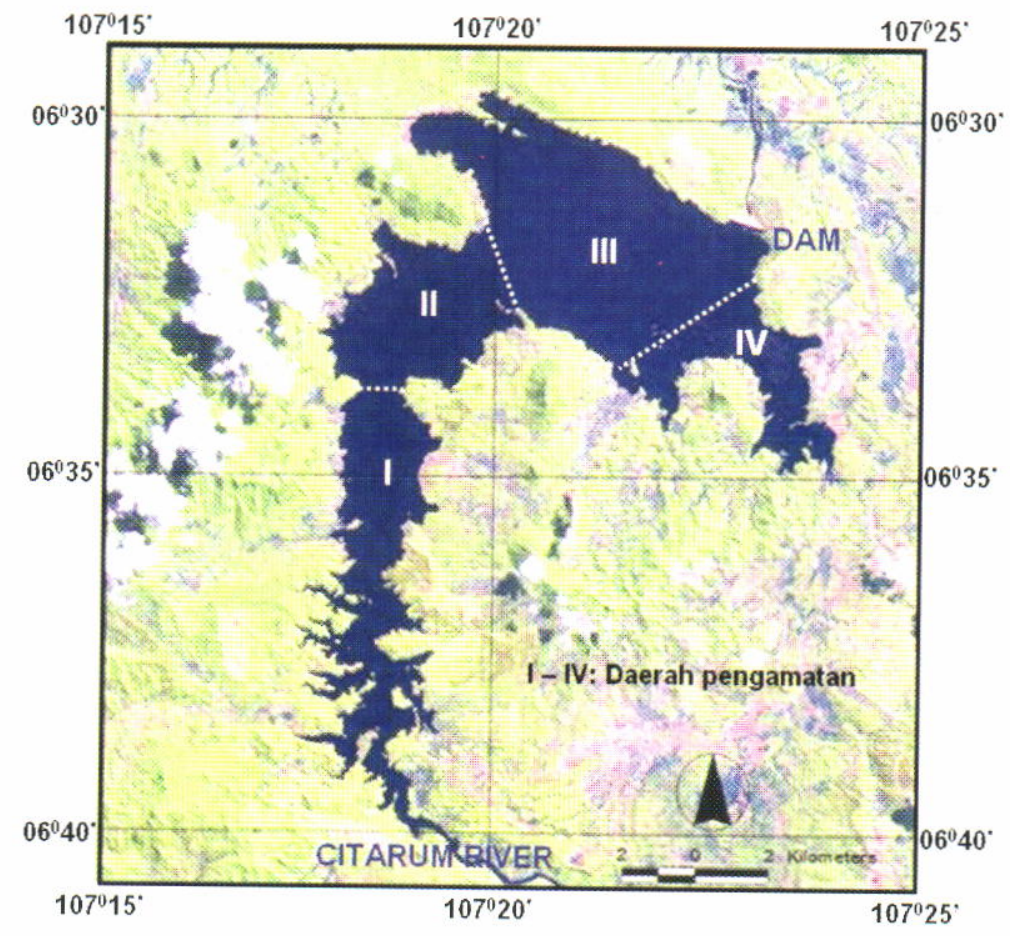

Gambar 1

Peta Waduk Djuanda dan 4 daerah pengamatan.

Figure 1.

Map of the Djuanda Reservoir and 4 observation areas.

makanan ikan tiap spesies dibedakan menurut kelas ukuran panjang total. Total volume dan frekuensi kejadian jenis makanan ikan dihitung untuk setiap contoh.

Jenis-jenis makanan alami yang dikonsumsi oleh ikan diketahui dengan cara menganalisis isi saluran pencernaan kemudian dihitung memakai metode indeks preponderan (Natarajan \& Jhingran yang dikutip oleh Effendie, 1979), yaitu:

$$
I i=\left(\frac{\left(V_{i} * O_{i}\right)}{\sum\left(V_{i} * O_{i}\right)}\right) * 100 \%
$$

di mana:

$\mathrm{I}_{i} \quad=$ indeks prepoderan jenis makanan ke- $i$

$\mathrm{V}_{i} \quad=$ persentase volume pakan ke- $i$

$\mathrm{O}_{i}=$ persentase kejadian pakan ke- $i$

Nilai luas relung makanan (niche breadth) untuk masing-masing jenis ikan dihitung berdasarkan pada persamaan Levins (1968) sebagai berikut:

$$
B=\frac{1}{\sqrt{p_{j}^{2}}}
$$

di mana:

$\mathrm{B}=$ nilai luas relung makanan ikan

$\mathrm{p}_{\mathrm{j}}=$ proporsi kategori makanan ke-j

Semakin tinggi nilai $B$, maka semakin luas dan beragam kategori makanan yang dapat dimanfaatkan oleh ikan dan sebaliknya.
Sedangkan tumpang tindih makanan (diet overlap) di antara jenis ikan dihitung menggunakan indeks similaritas Schoener's (Schoener, 1970) sebagai berikut:

$$
S=1-0.5\left(\sum_{i=1}^{n}|p x i-p y|\right)
$$

di mana:

$$
\begin{aligned}
\text { pxi }= & \text { proporsi kategori makanan i dalam } \\
& \text { makanan yang dikonsumsi oleh spesies } \\
& x \\
\text { pyi }= & \text { proporsi kategori makanan i dalam } \\
& \begin{array}{l}
\text { makanan yang dikonsumsi oleh spesies } \\
\end{array} \\
n= & \text { jumlah kategori makanan }
\end{aligned}
$$

Nilai $\mathrm{S}$ berkisar antara 0 sampai dengan 1 , nilai $\mathrm{S}$ lebih besar dari 0,6 secara biologis sudah nyata (biologically significant) menunjukkan kompetisi dalam memanfaatkan sumber daya pakan.

\section{HASIL DAN BAHASAN}

\section{Struktur Komunitas Ikan}

Struktur komunitas ikan di wilayah limnetik Waduk Djuanda yang didapat dari hasil percobaan penangkapan selama bulan Mei 2003 sampai dengan April 2004 tersusun dari 7 jenis ikan yaitu ikan bandeng (Chanos chanos), nila (Oreochromis 
niloticus), oskar (Amphilophus citrinellus), kongo (Tilapia butikoferi), mas (Cyprinus carpio), jambal (Pangasius hypopthalmus), dan kebogerang (Mystus nigriceps) dengan jumlah hasil tangkapan seperti tertera pada Tabel 1. Di samping ke-7 jenis ikan tersebut ditemukan pula ikan kaca (Chanda punctulada) yang mempunyai ukuran tubuh kecil sehingga jarang tertangkap dengan jaring insang ukuran mata lebih besar dari 1,0 inci. Dari jenisjenis ikan yang tertangkap, hanya 1 jenis yang merupakan ikan asli Sungai Citarum, yaitu ikan kebogerang, jenis ikan lain merupakan ikan eksotik baik yang ditebarkan (misal ikan nila dan jambal) maupun yang masuk ke perairan tidak disengaja atau lolos dari karamba jaring apung. Dari ke-7 jenis ikan yang tertangkap, 4 jenis ikan yaitu ikan bandeng, oskar, kongo, dan nila mendominasi hasil tangkapan. Sampai dengan saat ini, keberadaan ikan oskar dan kongo belum diketahui asal, namun diduga terbawa bersama benih ikan nila yang dipelihara di karamba jaring apung.

Tabel 1 juga menggambarkan distribusi horisontal dari jenis-jenis ikan yang menghuni wilayah limnetik. Empat jenis ikan yang mendominasi hasil tangkapan terdistribusi di ke-4 daerah penangkapan, sebaliknya ikan mas, jambal, dan kebogerang hanya tertangkap di daerah penangkapan III dan IV yang merupakan wilayah kegiatan budi daya ikan. Distribusi spasial dan temporal dari ke-7 jenis ikan yang tertangkap di wilayah limnetik tertera pada Gambar 2.

Berdasarkan pada stasiun pengamatan, keragaman jenis maupun jumlah ikan yang tertangkap paling banyak terjadi di stasiun III dan IV. Stasiun ini merupakan genangan utama waduk dan daerah budi daya ikan dalam karamba jaring apung. Hal ini, mengindikasikan bahwa keberadaan ikan bandeng, nila, dan mas di stasiun III dan IV berasal dari ikan yang terlepas dari budi daya ikan dalam karamba jaring apung. Berbeda dengan ikan nila dan mas, distribusi ikan bandeng ternyata cukup jauh sampai dengan ke stasiun I (daerah bagian hulu waduk), karena ikan bandeng bersifat perenang cepat dan peruaya sesuai bentuk tubuh yang silindris dan torpedo.

Berdasarkan pada periode penangkapan, frekuensi tertangkap ikan yang paling banyak terjadi pada bulan Agustus, September, Oktober 2003, dan April 2004, sedangkan yang terendah terjadi pada bulan Januari dan Pebruari 2004. Ikan bandeng paling banyak tertangkap pada bulan Oktober 2003, ikan oskar banyak tertangkap pada bulan Agustus 2003 dan April 2004, ikan kongo pada bulan April 2004 dan ikan nila banyak tertangkap mulai bulan Agustus sampai dengan Oktober 2003 dan April 2004. Fluktuasi hasil tangkapan ini nampak berkaitan erat dengan fluktuasi permukaan air waduk (Gambar 3). Pada waktu permukaan air waduk tinggi, hasil tangkapan ikan rendah dan meningkat sejalan dengan menurun tinggi permukaan air untuk kemudian mencapai hasil tangkapan tertinggi pada waktu permukaan air terendah. Kondisi seperti ini dapat dimengerti karena pada waktu permukaan air waduk tinggi, volume air waduk akan meningkat sehingga kelimpahan ikan di wilayah limnetik akan relatif rendah, sebaliknya pada waktu permukaan air rendah, volume air waduk akan rendah sehingga kelimpahan ikan akan relatif tinggi. Pada waktu kelimpahan ikan rendah, maka peluang ikan tertangkap akan rendah dan sebaliknya pada waktu kelimpahan ikan tinggi, maka peluang ikan tertangkap akan tinggi pula.

Distribusi panjang total ikan yang dominan tertangkap yakni ikan bandeng, nila, oskar, dan kongo tertera pada Gambar 4. Ikan bandeng pada

Tabel 1. Jumlah jenis ikan yang tertangkap di setiap daerah penangkapan wilayah limnetik Waduk Djuanda selama periode bulan Mei 2003 sampai dengan April 2004

Table 1. Number of fish species caught at every fishing area of the limnetic zone of Djuanda Reservoir during the period of May 2003 to April 2004

\begin{tabular}{clcccc}
\hline \multirow{2}{*}{ No. } & \multirow{2}{*}{ Jenis ikan/Fish species } & \multicolumn{4}{c}{ Daerah penangkapan/Fishing area } \\
\cline { 3 - 6 } & & I & II & III & IV \\
\hline 1. & Bandeng (Chanos chanos) & 18 & 1 & 77 & 75 \\
2. & Oskar (Amphilophus citrinellus) & 46 & 10 & 134 & 105 \\
3. & Kongo (Tilapia butikoferi) & 23 & 13 & 116 & 15 \\
4. & Nila (Oreochromis niloticus) & 18 & 4 & 47 & 14 \\
5. & Mas (Cyprinus carpio) & 0 & 0 & 6 & 3 \\
6. Jambal (Pangasius hypopthalmus) & 0 & 0 & 1 & 2 \\
7. & Kebogerang (Mystus nigriceps) & 0 & 0 & 2 & 0 \\
\hline & Total (individu) & $\mathbf{1 0 5}$ & $\mathbf{2 8}$ & $\mathbf{3 8 3}$ & $\mathbf{2 1 4}$ \\
\hline
\end{tabular}


A

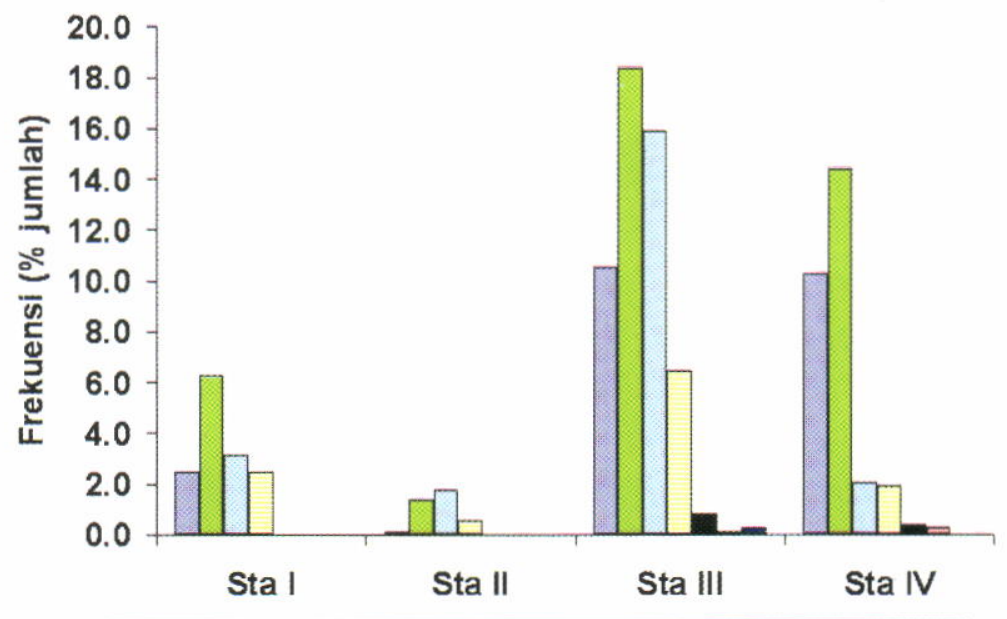

$\square$ Bandeng $\square$ Oskar $\square$ Kongo $\square$ Nila $\mathbf{m a s} \square$ Jambal $=$ Kebogerang

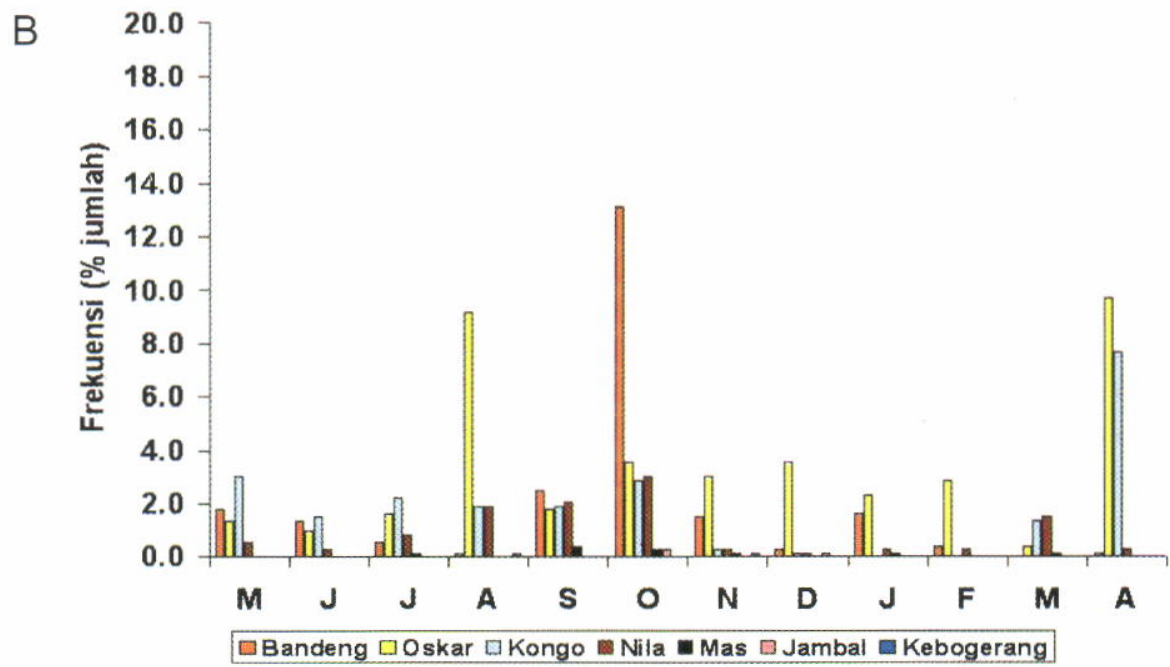

Gambar 2. Distribusi spasial (A) dan temporal (B) jenis ikan yang tertangkap di wilayah limnetik Waduk Djuanda selama periode bulan Mei 2003 sampai dengan April 2004.

Figure 2. Spatial (A) and temporal (B) distribution of fish species caught at limnetic zone of the Djuanda Reservoir in the period May 2003 to April 2004.

umumnya tertangkap pada kisaran panjang antara 20,5 sampai dengan $26,5 \mathrm{~cm}$; ikan nila pada kisaran panjang 18,5 sampai dengan $26,5 \mathrm{~cm}$; ikan oskar pada kisaran panjang 10,5 sampai dengan $18,5 \mathrm{~cm}$ dan ikan kongo pada kisaran panjang 11,5 sampai dengan $18,5 \mathrm{~cm}$. Ukuran kisaran panjang untuk ke-4 jenis ikan tersebut termasuk ke dalam fase ukuran ikan dewasa.

\section{Makanan dan Kebiasaan Makan Ikan}

Contoh ikan yang memenuhi syarat untuk dianalisis kebiasaan makanan di wilayah limnetik Waduk Djuanda selama pengamatan bulan Mei 2003 sampai dengan April 2004 adalah ikan bandeng, nila, oskar, dan kongo. Total contoh ikan bandeng yang diteliti 161 ekor dengan kisaran panjang total antara 12,5 sampai dengan $34,5 \mathrm{~cm}$; ikan nila 102 ekor dengan panjang total antara 8,5 sampai dengan $36,5 \mathrm{~cm}$; ikan oskar 332 ekor dengan ukuran panjang total antara 7,5 sampai dengan 21,5 cm; dan ikan kongo 164 ekor dengan ukuran panjang total antara 7,5 sampai dengan $19,5 \mathrm{~cm}$. Komposisi makanan berdasarkan pada indeks preponderan untuk ke-4 jenis ikan tersebut tertera pada Gambar 5.

Ikan bandeng dan nila memanfaatkan fitoplankton sebagai sumber pakan utama, sedangkan makanan tambahan berupa detritus untuk ikan bandeng, zooplankton, dan detritus untuk ikan nila.

Ikan oskar dan kongo mempunyai jenis pakan yang sama dinamai fitoplankton dan zooplankton merupakan pakan utama sedangkan potongan ikan 


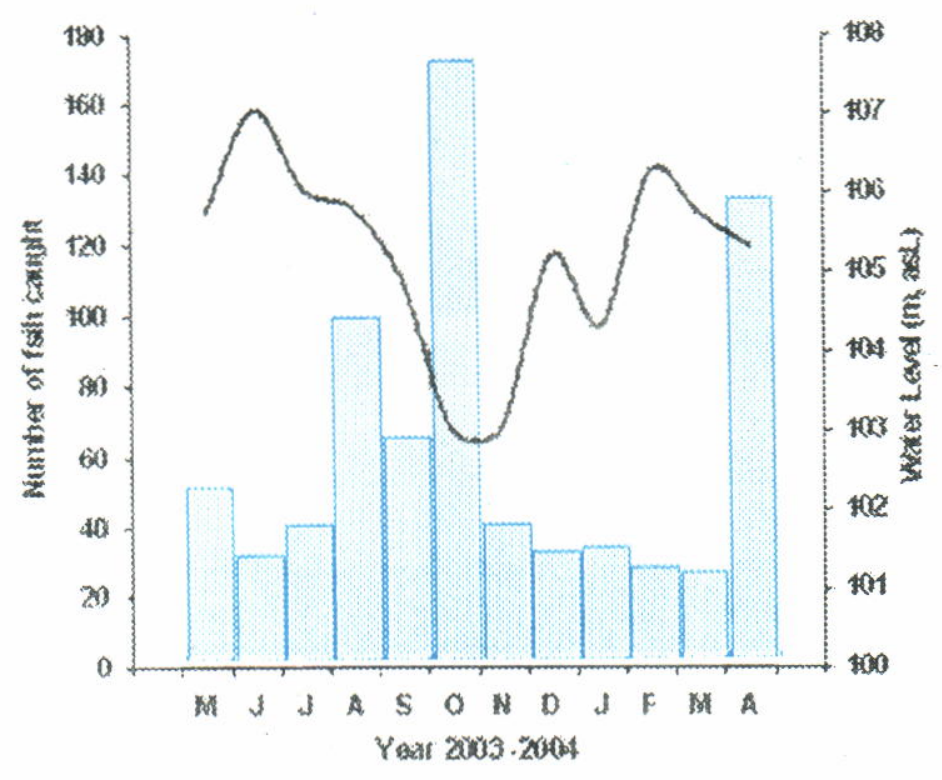

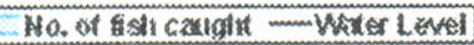

Gambar 3. Hubungan antara jumlah ikan yang tertangkap dan fluktuasi permukaan air Waduk Djuanda selama periode bulan Mei 2003 sampai dengan April 2004.

Figure 3. Relation between number of fish caught and water level of the Djuanda Reservoir during the period of May 2003 to April 2004.

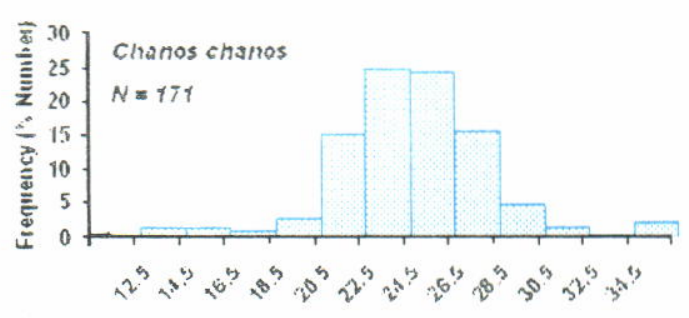

Mis Lenstli (Cin)

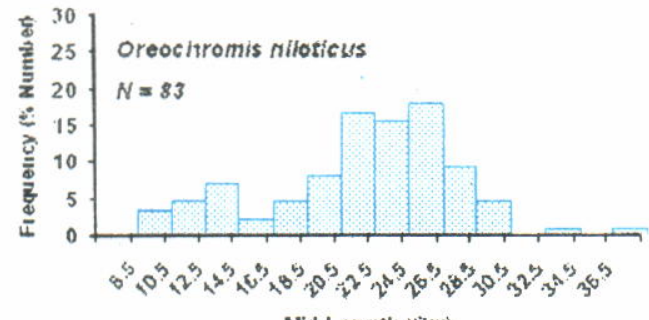

Mirl Lengtlı (C)
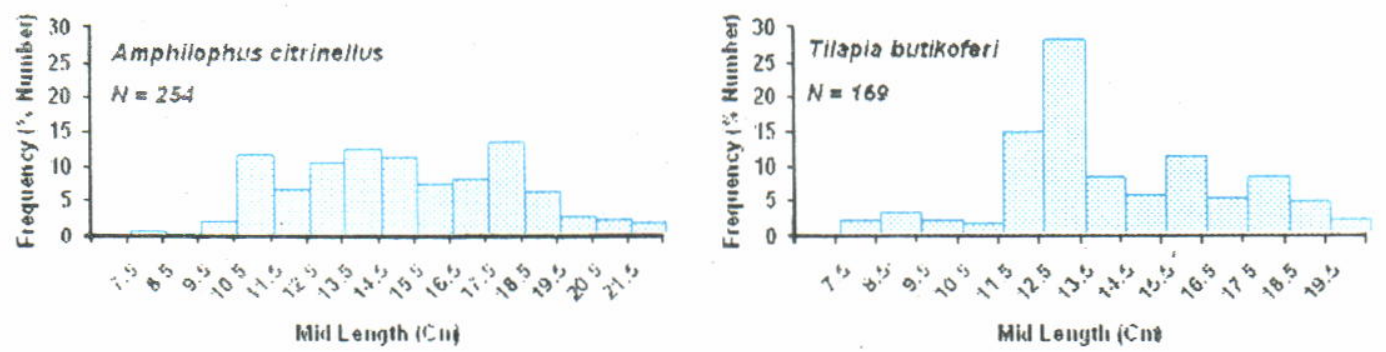

Gambar 4. Distribusi frekuensi panjang total ikan yang dominan tertangkap di wilayah limnetik Waduk Djuanda selama periode bulan Mei 2003 sampai dengan April 2004.

Figure 4. Length frequency distribution of the dominant species caught at limnetic zone of the Djuanda Reservoir in the period May 2003 to April 2004. 

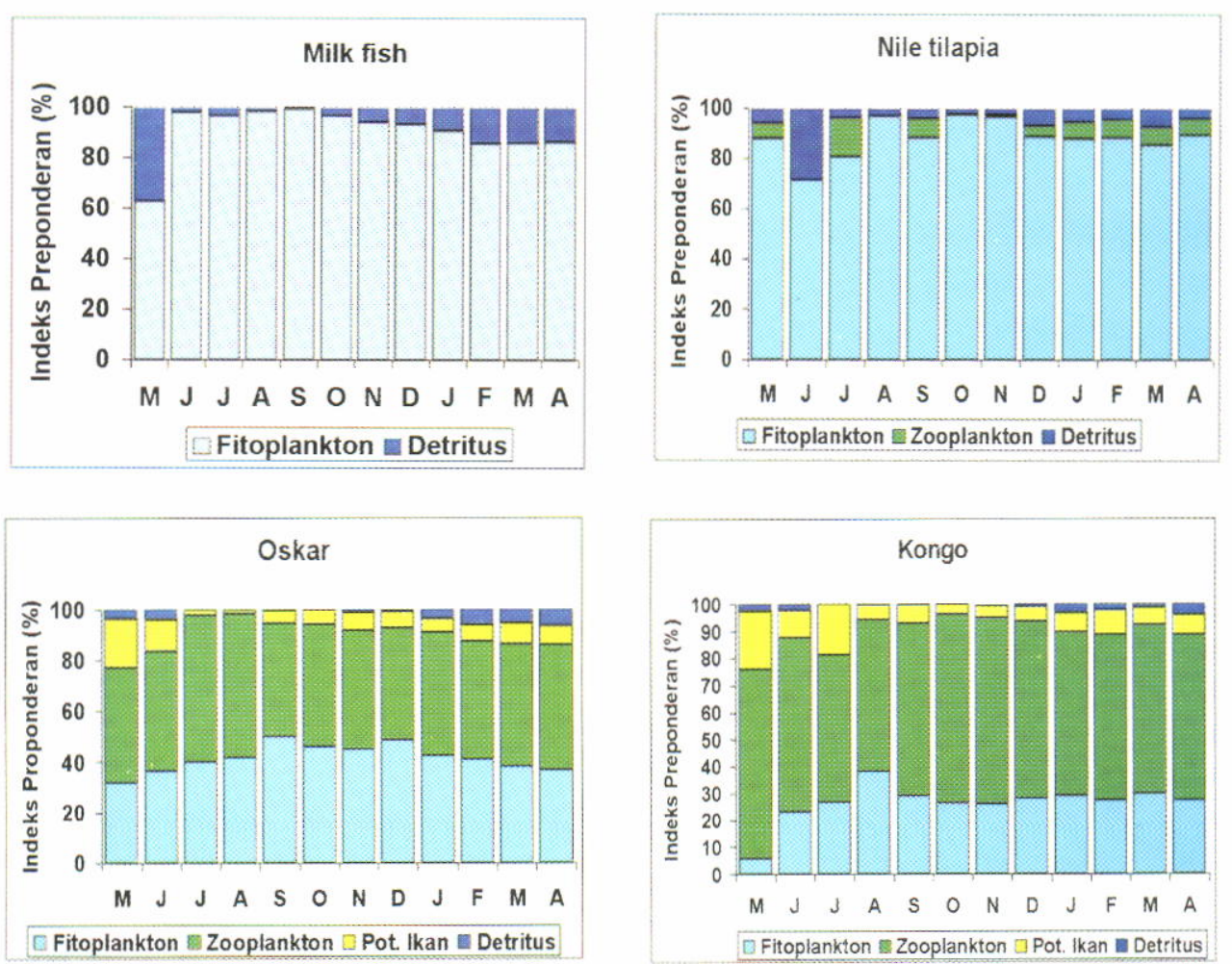

Gambar 5. Indeks preponderan makanan ikan bandeng, nila, oskar, dan kongo di Waduk Djuanda selama pengamatan bulan Mei 2003 sampai dengan April 2004.

Figure 5. The preponderance index of milk fish, nile tilapia, oskar, and kongo diets at Djuanda Reservoir during observation of May 2003 to April 2004.

dan detritus merupakan pakan tambahan. Kedua jenis ikan yang terakhir ini dapat dikategorikan sebagai ikan omnivor yang cenderung bersifat karnivora. Hal ini, terlihat dari nilai indeks preponderan untuk zooplankton dan potongan ikan yang relatif lebih besar jika dibandingkan dengan fitoplankton dan detritus.

Luas relung makanan ikan oskar dan kongo jauh lebih besar jika dibandingkan dengan relung makanan ikan bandeng dan nila. Hal ini, mengindikasikan bahwa ikan oskar dan kongo mampu memanfaatkan ketersediaan sumber daya pakan lebih lebar dan bervariasi (Tabel 2).
Nilai tumpang tindih makanan di antara ke-4 jenis ikan tertera pada Tabel 3. Dari Tabel 3 tersebut terlihat bahwa nilai tumpang tindih terbesar terjadi di antara ikan nila dan bandeng dan antara ikan kongo dan oskar, sedangkan nilai tumpang tindih terkecil terjadi antara ikan bandeng dan kongo ataupun ikan nila dan kongo. Nilai tumpang tindih yang besar menandakan bahwa ke2 jenis ikan tersebut mempunyai peluang kompetisi makanan yang besar. Wallacea (1981) mengatakan bahwa nilai tumpang tindih makanan antar jenis ikan lebih besar dari 0,6 secara biologis sudah menunjukkan kompetisi pemanfaatan sumber daya pakan yang nyata. Dalam hal ini,

Tabel 2. Rata-rata indeks preponderan dan luas relung makanan ikan bandeng, nila, oskar, dan kongo di Waduk Djuanda selama pengamatan bulan Mei 2003 sampai dengan April 2004

Table 2. The average of preponderance index and niche breadth of milk fish, nile tilapia, oskar, and kongo diets at Djuanda Reservoir in the period May 2003 to April 2004

\begin{tabular}{lcccc}
\hline \multicolumn{1}{c}{ Kategori makanan/ } & \multicolumn{4}{c}{ Indeks preponderan/Preponderance index (\%) } \\
\cline { 2 - 5 } \multicolumn{1}{c}{ Diets category } & Milk fish & Nile tilapia & Oskar & Kongo \\
\hline Phytoplankton & 90,60 & 88,21 & 41,64 & 26,59 \\
Zooplankton & 0,00 & 5,24 & 48,42 & 63,21 \\
Detritus & 9,40 & 6,55 & 2,67 & 1,36 \\
Fish fragment & 0,00 & 0,00 & 7,27 & 8,83 \\
Luas relung makanan/ & 1,21 & 1,27 & 2,42 & 2,09 \\
Niche breadth & & &
\end{tabular}


Tabel 3 .

Nilai tumpang tindih makanan ikan bandeng, nila, oskar, dan kongo di wilayah limnetik Waduk Djuanda selama pengamatan bulan Mei 2003 sampai dengan April 2004

Table 3. Niche overlap of milk fish, nile tilapia, oskar, and kongo at limnetic zone of the Djuanda Reservoir in the periode May 2003 to April 2004

\begin{tabular}{lcccc}
\hline \multicolumn{1}{c}{ Jenis ikan/Fish species } & Milk fish & Nile tilapia & Oskar & Kongo \\
\hline Milk fish & 1 & & & \\
Nile tilapia & 0,902 & 1 & 1 & \\
Oskar & 0,300 & 0,398 & 0,825 & 1 \\
Kongo & 0,125 & 0,223 & 0,825 \\
\hline
\end{tabular}

pemanfaatan makanan antara ikan nila dan bandeng serta antara ikan kongo dan oskar menunjukkan tingkat kompetisi yang sangat nyata. Sedangkan pemanfaatan sumber daya pakan antara ikan bandeng dengan ikan oskar dan kongo serta antara ikan nila dengan ikan oskar dan kongo tidak menunjukkan tingkat kompetisi yang nyata.

Ikan bandeng sebagai ikan pemakan plankton yang banyak memanfaatkan fitoplankton sebagai makanan utama dan hanya detritus sebagai makanan tambahan dapat dijadikan sebagai kandidat ikan tebaran untuk memanfaatkan fitoplankton yang berlimpah. Di samping itu, ikan ini juga dapat mengisi wilayah limnetik waduk, terdistribusi sampai dengan ke hulu waduk, tumbuh relatif cepat, dan mempunyai harga yang lebih tinggi dibandingkan dengan ikan nila dan mas (Kartamihardja \& Umar, 2005). Namun, karena ikan bandeng tidak dapat melakukan reproduksi di perairan waduk maka penebaran harus dilakukan berulang-ulang atau melalui program penebaran kembali (restocking).

\section{KESIMPULAN}

Struktur komunitas ikan di wilayah limnetik Waduk Djuanda didominasi oleh ikan eksotik yaitu oskar, kongo, bandeng, dan nila. Ikan bandeng dan nila dapat dikelompokkan ke dalam ikan pemakan plankton dengan makanan tambahan berupa detritus, sedangkan ikan oskara dan kongo dapat dikelompokan ke dalam ikan omnivora yang cenderung karnivora dengan makanan utama berupa zooplankton dan potongan ikan serta makanan tambahan fitoplankton. Ikan oskar dan kongo mempunyai luas relung makanan yang lebar jika dibandingkan dengan ikan bandeng dan nila. Tumpang tindih makanan yang besar terjadi antara ikan nila dan bandeng serta ikan kongo dan oskar. Ikan bandeng merupakan salah satu jenis ikan yang direkomendasikan untuk ditebar di Waduk Djuanda dalam rangka memanfaatkan kelimpahan fitoplankton yang tersedia.

\section{DAFTAR PUSTAKA}

Effendie, M. I. 1979. Metoda biologi perikanan. Yayasan Dewi Sri. Bogor. 112 p.

Jeffries, M. \& D. Mills. 1990. Freswater ecology: Principles and applications. Belhaven Press. London and New York. 285 p.

Kartamihardja, E. S. \& C. Umar. 2005. Capture fisheries component: Culture, capture conflicts, sustaining fish production, and livelihoods. The $2^{\text {nd }}$ Quarter ACIAR project. (unpublish).

Kartamihardja, E. S. \& A. Hardjamulia. 1983. Kontribusi penebaran ikan nila (Oreochromis niloticus) terhadap total produksi ikan di Waduk Juanda. Buletin Penelitian Perikanan Darat. Vol.1. No.1. 1983.

Kartamihardja, E. S. 1987. Pemantauan gill net untuk pendugaan produksi ikan di Waduk Juanda. Buletin Penelitian Perikanan Darat. Vol.6. No.1. 1987.

Levins, R. 1968. Evolution in changing environments: Some theoretical explorations. Princeton University Press. Princeton. New Jersey.

Sarnita, A. S. 1977. Some aspects of fisheries and their management in mane made lakes in Indonesia with special reference to Lake Jatiluhur. West Java. Procs. IPFC. 17(3): 272291. Bangkok.

Sarnita, A. S. 1987. Introduction and stocking of fish in lakes and reservoirs in Southeast Asian countries, with special references to Indonesia. FAO. Fish. Rep. No.371. pp.193-198.

Schoener T. 1970. Non synchronous spatial overlap of lizards in patchy habitats. Ecology 51: 408-418.

Wallace, R. K., Jr. 1981. An assessment of diet overlap indexes. Transactions of the American Fisheries Society. 110: 72-76. 